O. KORNELIUSZ T. WENCEL EC

\title{
KILKA ASPEKTÓW PUSTELNICZEGO DOŚWIADCZENIA WIARY
}

Ruch eremicki (gr. eremia - pustynia) towarzyszy Kościołowi od samych początków jego istnienia. Zawsze znajdowały się w nim osoby pragnące poświęcić swe życie samotności, milczeniu i ubóstwu, by na tej drodze, w sposób bardzo radykalny a zarazem prosty, osiagnąć upragnione zjednoczenie $z$ Bogiem i zbawienie. Pustelnictwo chrześcijańskie ma swe źródło w pierwotnej wewnętrznej potrzebie życia w samotności, które zdaje się być dla pewnej grupy osób, najpewniejszą drogą realizacji ewangelicznych Błogosławieństw. Eremita, opuszczając świat, nie czynił tego zatem nigdy w celu zaspokojenia swych indywidualnych pragnień przygody, sławy, niezwykłości. U podstaw doświadczenia pustelniczego, przynajmniej w rozumieniu, leży dar wezwania do zażyłego obcowania z Bogiem, w przestrzeni modlitwy kontemplacyjnej ${ }^{1}$.

Samotnicy pierwszych wieków udawali się do miejsc świętych, związanych ze starotestamentalną historią zbawienia. Również fenomen swoistego eksodusu mężczyzn i kobiet na przełomie III. i IV. wieku, zasiedlających rozległe pustynie Egiptu i Azji, można osadzić w tym kontekście. W wielu przypadkach miejsca te odwoływały się w sposób bezpośredni, lub przynajmniej na zasadzie ukształtowanej tradycji, do konkretnych zdarzeń z historii biblijnej ${ }^{2}$.

Rozkwit życia pustelniczego w Kościele zachodnim przypada na IV w., kiedy to Atanazy Wielki napisał żywot Antoniego Pustelnika. W tym czasie pustelnicy pojawiają się we Włoszech i sąsiadujących wyspach. Około roku 360 Marcin z Tours założył wioskę pustelniczą w Marmoutier dla 80 osób, kapłanów i świeckich. W tym czasie w Galii powstał cały szereg pustelni, których charakterystyczną cechą było łączenie eremityzmu z życiem wspólnotowym, z jednoczesnym okresowym podejmowaniem działalności apostolskiej. Następnie eremityzm krzewił się w Prowansji, zwłaszcza na wyspach Lerynu, a także w Irlandii, Szkocji i Walii. Mnisi z Wysp Brytyjskich, urzeczeni ideałem ,pielgrzymowania dla Bo-

1 Por. M. Daniluk, Eremityzm, [w:] Encyklopedia Katolicka, t. 4, k. 1069-1078; C. L i a l i n e, P. D o y e r e, Eremitism, [w:] Dictionere de spiritualité, red. M. Viller, k. 936-983, Paris 1937.

${ }^{2}$ Por. K. W e n c e 1, Życie pustelnicze, Kraków 2000, s. 11. 
ga", udawali się na kontynent, by tutaj zakładać eremy, podejmując jednocześnie działalność apostolską. Pustelnicy żyjący indywidualnie nie uczestniczyli w kulcie liturgicznym i, poza chrztem, nie przyjmowali sakramentów. Wyrzeczenie się wszystkiego, ze względu na Chrystusa, uważano w tym czasie, za równoważnik sakramentu. Kolejny rozwój życia pustelniczego na Zachodzie obserwuje się w wieku XI. W poszukiwaniu doktryny, odnoszono się do tradycji biblijnej i patrystycznej, akcentując surową samotność i ubóstwo. Jest to również czas stopniowego przechodzenia od surowych praktyk pokutniczych, na rzecz bardziej wewnętrznego rozumienia powołania pustelniczego. Pod wpływem m.in. św. Hildegardy z Bingen, wskazywano na szkodliwość ciagłego wędrowania dla rozwoju życia duchowego. Dlatego też zaczęto mówić o „drodze wewnętrznej” (itinerarium) duchowego rozwoju, z głęboką świadomością przemijalności wszystkiego, co doczesne. W takiej perspektywie klasztor staje się „pustynia”, a „wyjście” (exodus) to decyzja opuszczenia wszystkiego, co związane z egoizmem ${ }^{3}$.

\section{ROMUALDOWE DZIEDZICT WO}

Wydaje się, że początkową intencją św. Romualda z Rawenny, który w drugiej połowie X. w. gromadził wokół siebie zarówno poszczególnych uczniów, jak i male grupy eremitów we wspólnoty pustelnicze, nie było tworzenie nowej instytucji zakonnej. Chociaż w ciagu swego długiego życia reformował i zakładał klasztory, główny akcent swej reformatorskiej misji w sposób zdecydowany przesunął w stronę odnowy życia pustelniczego w Kościele Zachodnim ${ }^{4}$. Trudno ogarną́ bogactwo charyzmatu, którym został naznaczony, niemniej jednym z najwyrazistszych jego momentów była organizacja małych wspólnot pustelniczych, którym zapewnił duchowe przewodnictwo oraz regułę życia wspólnotowego. $Z$ tego powodu został nazwany „Ojcem rozumnych pustelników”, którzy żyją w posłuszeństwie Regule św. Benedykta oraz przełożonemu ${ }^{5}$. I choć sam nie pozostawił po sobie własnych spisanych nauk, dowiadujemy się o ich istocie $z$,Żywota św. Romualda" św. Piotra Damiana oraz "Żywota Pięciu Braci męczenników” św. Brunona ${ }^{7}$ oraz z „Reguly eremickie” bl. Rudolfa ${ }^{8}$.

Podstawowym terminem określającym specyfikę charyzmatu romualdowego jest „potrójne dobro" (triplex bonum), który pojawia się w Żywocie Pięciu Braci

\footnotetext{
${ }^{3}$ Por. tamże, s. 15 .

${ }^{4}$ Por. Mansue to Dell a Santa, Ricerche Sull'Idea Monastica di San Pier Damiano, Camaldoli 1961, s. 168.

${ }^{5}$ Por. P. B elis le, Primitive Romualdian/Camaldoles Spirituality, „Cisterician Studies Quarterly" 31:4 (1996) s. 414.

${ }^{6}$ Por. P. D a m i a n, The Life of Blesed Romuald, [w:] The Mystery of Romuald and the Five Brothers, Big Sur 1994.

${ }^{7}$ Por. Bruno of Que r furt, The Live of the Five Brothers, [w:] The Mystery of Romuald and the Five Brothers, Big Sur 1994.

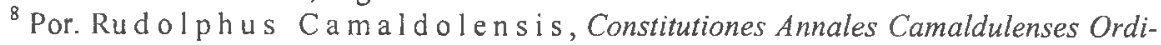
nis Sancti Benedicti... 9 vols, Venetiae 1755-1773 III, App., cols. 512-551.
} 
i odniesiony zostaje do szerszego kontekstu monastycznej tradycji ${ }^{9}$. Strukturę triplex bonum określa „coenobium" rozumiane jako życie wspólnotowe dla początkujących mnichów, „złota samotność” przeznaczona dla osób, które postapiły w doskonałości i dojrzeli do życia w trwałym zjednoczeniu z Bogiem w samotności oraz „Evangelium paganorum - Martyrium” "głoszenie Ewangelii poganom męczeństwo" dla tych, którzy pragną porzucić ten świat i żyć z Chrystusem ${ }^{10}$. $\mathrm{Z}$ teologicznego punktu widzenia ten trójczłonowy podział kamedulskiej drogi można odnieść do zasadniczych aspektów życia Jezusa: wspólnota uczniów, samotność-modlitwa oraz nauczanie. Istotę romulaldowej reformy można opisać jako syntezę opartą o Regułę św. Benedykta pomiędzy eremityzmem a cenobityzmem ze zdecydowanym wyeksponowaniem doświadczenia pustelniczego, którego strukturę buduje modlitwa, post, samotność i milczenie ${ }^{11}$.

Paweł Justyniani (1476-1528), reformator życia pustelniczego okresu Renesansu, to postać naznaczona głęboką kulturą humanistyczna, szerokimi intelektualnymi horyzontami, delikatnością i wrażliwością serca, połączoną z umiejętnością mądrej asymilacji bogatej tradycji eremickiej Kościoła ${ }^{2}$. Źródła proponowanej przezeń duchowości, w pełni rozwiniętej w założonej przezeń Kongregacji Pustelników Kamedułów Góry koronnej (1526), mają szeroki i zarazem złożony charakter. Ojciec Paweł z jednej strony czerpał obficie z myśli Cycerona i Seneki, którzy ostatecznie odegrali decydującą rolę w jego duchowym nawróceniu i wyborze drogi życia samotnego ${ }^{13} . \mathrm{Z}$ drugiej zaś strony studium Pisma świętego, dzieł Ojców Kościoła, średniowiecznych pisarzy monastycznych oraz wielkich scholastyków, określiło dogłębnie zarówno profil jego duchowości, jak i profil najistotniejszych egzystencjalnych poszukiwań i wyborów. Niewątpliwie jednak wywarła nań postać i dzieło św. Romualda, którego charyzmatyczne przesłanie w pelni odczytał i przeniósł na grunt Kościoła doby Renesansu ${ }^{14}$.

Ojciec Paweł podejmując się trudu kształtowania nowego instytutu zakonnego w sposób szczególnie mocny podkreślił drugi aspekt romualdowego triplex bonum a mianowicie „złotą samotność”. Podejmując próbę określenia istoty pustelniczego powołania pisze, iż jest ono „tym rodzajem życia, w którym człowiek, wyrzekłszy się troski o wszelkie sprawy doczesne lub duchowe zajmuje się jedynie Bogiem oraz - na ile pozwala na to ludzka słabość - stara się usilnie o zjedno-

${ }^{9}$ Por. T. M a t u s, The Mystery of Romuald nad the Five Brothers, Big Sur 1994, s. 95.

${ }^{10}$ Por. B. C a l a t i, Sapienza monastica. Saggi di storia, spiritualità e problemi monastici, Roma 1994, s. 530 n.

${ }^{11}$ Por. T. M at us, The Mystery..., dz. cyt., s. 214.

${ }^{12}$ Por. K. W e n c e 1, Moi mistrzowie duchowi, „Więż” $9(2000)$, s. 145.

${ }^{13}$ Por. J. L e c le r cq, Un umanista eremita. Il beato Paolo Giustiniani (1476-1528), Frascati 1975, s. 17 n.

${ }^{14}$ Por. tamże, s. 30 n. 
czenie z Bogiem z pomocą świętej lektury, przez rozważanie rzeczy wiecznych i gorliwą modlitwę"15.

\section{ELEMENTYEREMICKIEJ DUCHOWOŚCI}

Chodzi mu zatem o ukazanie drogi samotności, milczenia, modlitwy i postu jako swoistej formy dynamizowania, a zarazem spełnienia chrześcijańskiej drogi życia wiary, owocującego zjednoczeniem z Bogiem i braćmi ${ }^{16}$. Jego rozumienie i sposób ujmowania duchowości nie ogranicza się li tylko do wykładu zasad ascetyki czy też subtelnych analiz natury psychologicznej. W gruncie rzeczy jest to teologia wskazująca na centralny moment doświadczenia eremickiego, jakim jest Misterium Chrystusa otwierające się w rzeczywistości Bożego słowa i sakramentu. Stąd kluczowym elementem tej drogi jest samotna medytacja (lectio divina) nad darem słowa Bożego oraz pielęgnacja ducha liturgii eucharystycznej ${ }^{17}$.

\section{Lectio divina $w$ samym centrum praktyki monastycznej}

W najstarszej tradycji chrześcijańskiej lektura Pisma Świętego (lectio) prowadziła do glębokiego rozważania (meditatio) przyjętego słowa, by następnie przejść w modlitwę (oratio), a w konsekwencji do postawy pełnej adoracji i uwielbienia (contemplatio) ${ }^{18}$. Ta patrystyczna praktyka została następnie przejęta przez środowiska mnichów, dla których modlitwa kontemplacyjna była owocem lektury i rozważania Pisma. Jej początek określała pełna afirmacja, $\mathrm{w}$ prawdzie i miłości, usłyszanego słowa, która przeobrażała się następnie w kontemplację rozumianą jako dialog miłości. Zwieńczenie całego procesu stanowiło mistyczne zjednoczenia $\mathrm{z}$ Bogiem przejawiające się często głębokim pragnieniem męczeństwa.

Średniowieczny proces racjonalizacji wiary sprawił, iż kontemplacja rozwijała się niejako obok głównego prądu teologicznego, jakby na jego obrzeżach. Autentyczne przeżycie religijne stopniowo oddalało się od swych podstawowych źródeł, jakimi pozostają Biblia i teologia. Coraz mniej czytelna liturgia sprawowana po łacinie przestawała karmić pobożność szerszych kręgów wiernych ${ }^{19}$.

W minionym stuleciu na kanwie posoborowych zmian sytuacja doznała dość radykalnego zwrotu. Odnowa teologii w duchu biblijnym i patrystycznym umożliwiła przywrócenie lectio divina jej właściwego miejsca w wymiarze życia Kościoła. Sobór wskazuje, iż źródłem odnowy chrześcijańskiej pozostaje słowo Boże

${ }^{15}$ Konstytucje Kongregacji Pustelników Kamedutów Góry Koronnej, Kraków 1991, s. 11

${ }^{16}$ Por. P. G i u s t i n i a n i, Regola della vitae eremitica, Monte Rua 1984, s. 17.

${ }^{17}$ Por. tamze, s. 29 n.

${ }^{18}$ Por. A. J a n k ow s k i, Czytanie Pisma Świętego, [w:] Lectio divina. Boże czytanie, red. W. Zatorski, Kraków 1991, s. 10 n.

${ }^{19}$ Por. tamże. 
prowadzące do poznania Chrystusa. Lekturze winna towarzyszyć ożywiona modlitwa rozumiana jako rozmowa człowieka z Bogiem (zob. DV 25) ${ }^{20}$.

Jak zaznaczono tradycja monastyczna przez całe wieki pielęgnowała formę rozmyślania zwaną lectio divina, która wychodząc od studium Pisma i jego rozważanie prowadzi do prostej modlitwy kontemplacyjnej. Ten rodzaj modlitwy opiera się na aktach wiary i miłości ożywiających postawę adoracji i uwielbienia ${ }^{21}$.

Lectio divina jest dla mnicha „ćwiczeniem duchowym”, konkretną drogą życia, myślenia, modlitwy, który obejmuje sobą całość jego osobowości ${ }^{22}$. To duchowe „ćwiczenie” w tradycji monastycznej to nie ,rekolekcje”, lecz wysiłek zasadniczego nakierowania całości naszego życia na danie pozytywnej odpowiedzi przywołujacemu nas Bożemu słowu. Jest ona swoistą droga stopniowej przemiany serca, osobowości, całego życia ${ }^{23}$. Skupia ono w sobie jak w soczewce całość naszej mniszej postawy, której istota odnosi się do tego, co św. Benedykt nazywa „szukaniem Boga”, które wyraża nasze dążenie do doskonałości czy też zbawie$n^{24}$. Bezsprzecznym znakiem owego poszukiwania Boga jest taka otwartość wiary, dzięki której żyjemy „przez" Chrystusa, „z" Chrystusem i „w” Chrystusie. Mnich jako człowiek drogi wiary przypomina uczniów z Emaus; podąża z Chrystusem, lecz nie jest w stanie Go rozpoznać. Jednakże dzięki pokorze i czystości serca ze zdumieniem odkrywa, iż Chrystus towarzyszy mu, już-od-zawsze", że to On nieustannie go szuka, a człowiek w końcu przychodzi do Niego. Skryta obecność Boga w naszej codzienności prowokuje w nas wysiłek wiary, dzięki któremu odkrywamy fundamentalny dla naszego chrześcijańskiego doświadczenia fakt, iż Chrystus jest z nami, nieustannie towarzyszy nam i wspiera. My ciagle nie jesteśmy do końca z Nim, jednakże On w sposób zupełny i wyłączny pozostaje nam wierny. Jest to obecność w Bożym słowie, sakramencie, wspólnocie. Jedynie w świetle słowa jesteśmy zdolni otworzyć oczy na przebóstwiające paschalne światło płynące $\mathrm{z}$ postaci Zmartwychwstałego. W tymże świetle rozpoznajemy nie tylko obecność nieustannie przychodzącego Pana, lecz również ostateczny sens i kres naszej drogi wiary ${ }^{25}$.

W codziennym życiu monastycznym osadzonym w konkretnym pustelniczym charyzmacie podejmujemy szereg duchowo-ascetycznych praktyk, które mają nas przybliżyć do spotkania z Bożym królowaniem. Należą do nich medytacja, posłuszeństwo, post, modlitwa, milczenie, czy pokora. Wszystkie one sa, jak mówi św. Benedykt „narzędziami dobrych uczynków”, a więc konkretnym miejscem udzielania się Bożego Ducha, który prowadzi nas do ostatecznego celu naszej ziemskiej podróży ${ }^{26}$. Praktyki życia monastycznego nie można zamknąć w schemacie "planu dania" a więc szeregu mniej lub bardziej ważkich czynności,

${ }^{20}$ Konstytucja dogmatyczna o Objawieniu Bożym „Dei Verbum” (dalej: DV), Sobór Watykański II. Konstytucje, Dekrety, Deklaracje, Poznań 1967.

${ }^{21}$ Por. A. Jank owski, art. cyt., s.11.

${ }^{22}$ Por. P. H a d o t, Exercices spirituel et philosophie antique, Paris 1987.

${ }^{23}$ Por. T. M e r t o n, Basic Principles of Monastic Spirituality, Gethsemani 1957, s. 5 n.

${ }^{24}$ Por. P. H a d o t, Exercises spirituals et philosophie antique, Paris 1987.

${ }^{25}$ Por. A. Ja n kowski, art. cyt., s. 12.

${ }^{26}$ Por. M. d e D re uill e, The Rule of Saint Benedict, New York 2000, s. $86 \mathrm{n}$. 
które należy podjąć, lecz w swej istocie odnosi się ona doświadczenia wiary ożywianej tchnieniem Parakleta. Doświadczenie monastyczne ma charakter „duchowy" nie z tej racji, iż mnich praktykuje surową ascezę i wiele godzin poświęca na modlitwę, lecz jedynie dlatego, iż jest ono otwarte na tchnienie Ducha Świętego ${ }^{27}$.

Mnich jako człowiek zawierzenia żyje w przestrzeni udzielania się Ducha Świętego, choć możliwość otwarcia jego wolności na proces samoudzielania się Boga bywa ograniczany jego słabością czy wręcz grzechem. Istota życia monastycznego nie odnosi się zatem nade wszystko do praktyki określonych zasad etycznych, lecz wprost do teologicznego doświadczenia nadziei, które owocuje całkowitym wydaniu się w Boże władanie. Duch jest tą energią palaryzującą nasze życie, mocą której poszukujemy i odnajdujemy Boga w naszej codzienności, pomimo ograniczeń i grzechu ${ }^{28}$.

Sercem życia kamedulskiego jest nieustanne poszukiwanie Boga „z", „przez” oraz „w” Chrystusie. Z chwilą, gdy tracimy z oczu zasadniczą prawdę naszego powołania, iż to Chrystus jest naszym życiem przestajemy być nie tylko mnichami, ale i chrześcijanami ${ }^{29}$.

Lectio divina jest zasadniczą praktyką życia mnicha właśnie dlatego, iż pozostaje najskuteczniejszą drogą poszukiwania Ojca za pośrednictwem Bożego słowa dzięki mocy Ducha. Jest ono codzienną praktyką mnicha, która otwiera „oko" jego wiary na paschalne światło łaski płynącej z wydarzenia spotkania z Bożym słowem. Lectio pozostaje zasadniczo praktyką recepcji słowa, w kontekst której zostaje włączone nasze doświadczenie milczenia, samotności, postu i modlitwy. ${ }^{30}$ Dlatego możemy powiedzieć, iż jedynie ono jest niezbędne do autentycznej realizacji monastycznego posłannictwa, gdyż nadaje mu nie tylko właściwy kształt, lecz także kierunek i ostateczny sens. Słuchanie słowa ze zrozumieniem w wierze prowadzi do przeniknięcia Bożego misterium ( $\mathrm{kk} 8,21)$ i określa podłoże wszelkiej zdrowej refleksji teologicznej, do której jako chrześcijanie jesteśmy wezwani $^{31}$. Słyszymy aż nazbyt często i to nie tylko w środowiskach osób świeckich, lecz także mnichów, iż istnieje nieprzekraczalna granica pomiędzy trudną, abstrakcyjnie ujętą teologią spekulatywną a chrześcijańską duchowością ${ }^{32}$. Jednakże bez zdrowej, trzeźwej refleksji teologicznej nie sposób przyjąć i zasymilować bogactwa treści jakie niesie w sobie Biblia czy też chrześcijańskie przesłanie mistyczne. Każda droga teologicznych poszukiwań ma nie tylko swą metodę, lecz można powiedzieć, że sama w sobie jest metodą. Każda autentyczna metoda jest swoistą syntezą pomiędzy myślą i życiem; nasz sposób życia podąża za myślą i na odwrót ${ }^{33}$.

${ }^{27}$ Por. L. Fre e ma n, Purity of Hart, [w:] Purity of Hart and Contemplation, red. B. Bernhart and J. Wong, New York 2001, s. $247 \mathrm{n}$.

${ }^{28}$ Por. tamże, s. 257 n.

${ }^{29}$ Por. H. U. v on B a 1 th a s a r, Prayer, London 1966, s. 66.

${ }^{30}$ Por. D. Corcora n, Benedictine Humility and Confucian "Sincerity", [w:] Purity of Hart, dz. cyt., s. 237.

${ }^{31}$ Por. K. W e n c e l, Milczenie, Kraków 2001, s. 96 n.

${ }^{32}$ Por. J. O' D o n n e 11, The Mistery of the Triune God, London 1988, s. VII.

${ }^{33}$ Por. K. W e n c e 1, Milczenie, dz. cyt., s. 44 nn. 
Nie jest rzeczą łatwą oddanie treści pojęcia lectio divina w językach nam współczesnych. Lectio, w jego pierwotnym znaczeniu, oznacza powolne rozumne czytanie słowa Bożego prowadzące nas do jego „słyszenia” i „rozumienia” sercem. Termin ten nie odnosi się jedynie do czytania, lecz do „przeżuwania” (ruminatio) i asymilacji słowa. W naszym codziennym doświadczeniu treść słowa dociera do nas w kontekście lektury Pisma świętego, jak i codziennego wshuchiwania się w teksty niesione przez liturgię ${ }^{34}$. Uważna recepcja słowa w perspektywie wiary przekłada się na całodzienną praktykę ciagłego przypominania sobie i powtarzania posłyszanych treści w ciagu całego dnia. Ciagle świadome trwanie w wierze przy posłyszanym słowie jest procesem, który nazywamy meditatio. Należy jednak pamiętać, iż medytacja stanowi jedynie jeden z momentów lectio divina i nie może wyczerpać jej treści. Ruminatio odnosi się do ustawicznego zwrócenia naszej świadomości wiary w stronę Bożego słowa, które przemawia w naszym sercu z całą swą mocą. Prowadzi ono do nawiązania żywej relacji wiary i miłości między nami i Bogiem. Dzięki niej zaczynamy poznawać Boga na drodze uczestnictwa, zjednoczenia i miłości.

Nasi zakonnicy ,niech codziennie mają w ręku Pismo Święte, aby z lektury i rozważania ksiag świętych czerpali przewyższającą wszystko wiedzę Jezusa Chrystusa"(por. Flp 3,8). Taki stały kontakt ze słowem Bożym jest pierwszym i podstawowym elementem, ,lectio divina”, której pustelnicy oddaja się przynajmniej dwie godziny dziennie. "Lectio divina" to więcej niż samo tylko czytanie. Istotnie, byłoby to zbyt mało tylko czytać, jeśliby po czytaniu nie następowało rozmyślanie, które sprawia, że słowo Boże tym bardziej przenika nasze wnętrze ${ }^{35}$.

Lectio divina nie jest zatem jedynie pobożną lekturą Pisma, lecz nade wszystko wydarzeniem doświadczenia spotkania z Bogiem w wierze, a więc uczestniczenia w wymianie miłości pomiędzy Ojcem i Synem. Treścią słowa jest Duch miłości, który wprowadza nas w przestrzeń pierwotnej modlitwy pomiędzy Ojcem i Synem ${ }^{36}$.

Każde lectio prowadzi nas do oratio i na odwrót. Chrześcijańska modlitwa wpisana jest w kontekst spotkania z Bożym słowem a to spotkanie motywowane jest autentyczną modlitwą (oratio/lectio/oratio). Lectio uprzedza oratio i jest kluczem do wniknięcia w wewnętrzną duchową treść słowa. Penetracja ,ducha" słowa staje się źródłem impulsów pobudzającym ciągle na nowo nasze modlitewne spotkanie z Jezusem ${ }^{37}$.

„Rozmyślając, pustelnik uzdalnia się do lepszego rozpoznania głosu Pana zarówno w przeszłości, jak i jego osobistej historii zbawienia. Ponieważ bez pomocy Bożej nic nie znaczy czytanie i rozważanie, pustelnicy niech się oddają przede wszystkim i ponad wszystko modlitwie",38.

${ }^{34}$ Por. A. R a v i e r, Vita umana e vita divina nella mistica cristiana, [w:] La mistica e le mistiche, red. A. Ravier, Torino 1996, s. $58 \mathrm{n}$.

${ }^{35}$ Konstytucje..., dz. cyt., s. 29.

${ }^{36}$ Por. K. W e n c e 1, Oswajanie lwa, Warszawa 2000, s. 49 n.

${ }^{37}$ Por. D. G org e, "Saint Jèrome et la lecture sacrèe dans le milieu ascétiquw romain». La Lectio Divina. Des origines du cénobitisme à saint Benoit et Cassidore I, Paris 1925.

${ }^{38}$ Konstytucje..., dz. cyt., s. 29 n. 
Recepcja Bożego słowa jest zarazem ekspresją naszej wolności wobec Boga, jak i łaskawym działaniem Ducha Świętego w naszych sercach. Duch wyposaża nas w zmysł wiary, dzięki któremu możemy intuicyjnie wniknąć w głębie i treść misterium Bożego słowa i wypełnić się „nową" modlitwą dziękczynienia i chwały $\left(1\right.$ Kor 2, 10) ${ }^{39}$. Droga wiodąca do kontemplacji biegnie pomiędzy wzajemną relacją dwóch wolności Bożej i ludzkiej, wzajemnej otwartości i przepływu miłości inspirowanej mocą Ducha. Możliwość percepcji słowa (lectio) jest związana z decyzją samoudzielania się Boga i tym samym zostaje włączona w dynamikę życia trynitarnego. Słowo życia przychodzi do nas dzięki pośrednictwu Ducha; jest to słowo będące żywotnym wyrazem jedynego Obrazu Ojca, Jezusa Chrystusa.

Powołanie monastyczne jest służbą Bożą poprzez realizację ściśle kontemplacyjnego stylu życia, w kontekście którego ukazuje się trynitarny wymiar Bożej miłości. Lectio divina nie jest tutaj jednym ze sposobów interpretacji czy też medytacji nad tekstem Pisma, lecz sercem życia mniszego. Klasztor jako szkoła służby Pańskiej jest przestrzenia, w której wsłuchujemy się w słowo naszego Pana Jezusa Chrystusa ${ }^{40}$. Wszystkie elementy codziennej ascezy mnicha (samotność, post, milczenie, czystość wewnętrzna) zmierzają w kierunku uwrażliwienia serca do percepcji wiary. Jedynie w słowie i tylko dzięki niemu nasze ascetyczne wysiłki stają się warunkiem możliwości duchowego wzrostu. Powołanie monastyczne można uznać za taki dar łaski, dzięki której mnich poddaje się nade wszystko mocy słowa w przemianie serca. W praktyce oznacza to czytanie, medytację, powtarzanie slowa Pisma na co dzień.

Lectio ma swój początek w samotnym czytaniu Pisma w celi. Zgodnie z tradycja jest to czytanie na głos, które umożliwia „wsłuchiwanie" się treść słowa. W ten sposób czytanie synchronizuje z czynnością słuchania; lectio pozostaje uważnym ,po-słuchem" dawanym Bożemu słowu. Aby słuchać muszę wpierw posłyszeć słowo, toteż pierwszym krokiem na drodze lectio jest proklamacja Ewangelii. Czytamy powoli i uważnie tekst trzy lub cztery razy zaznaczając kilka milczących pauz $^{41}$.

Ćwiczenie czytania, powtarzania i słuchania słowa prowadzi nas do odkrycia samego jądra tekstu, jego wewnętrznej prawdy ożywiającej ducha kontemplacji. Może nim być słowo, bądź ich kompleks i wcale nie musi on korespondować z sensem egzegetycznym. Jest to centrum, które odkrywa przed nami Duch Święty, dzięki mocy intuicji wiary nie zaś wysiłkom samego tylko intelektu ${ }^{42}$.

Istnieją trzy obiektywne momenty wiary Kościoła, w odniesieniu do których moźemy zweryfikować osobiste odczytanie danego tekstu. Jest nim samo Pismo, liturgia Kościola oraz lokalna wspólnota. Nasz sposób rozumienia danego tekstu nie może być oderwany od przesłania i kontekstu całości Biblii, gdyż zgodnie z nauką Ojców Kościoła „Pismo tłumaczone jest poprzez Pismo”. Codzienne czytanie (lectio) Ewangelii w kontekście liturgii poprzedzone jest aklamacja alleluja zawierająca kluczowe zdanie do liturgicznej interpretacji danego fragmentu.

\footnotetext{
${ }^{39}$ Por. St. A u g u s t in e, De doctrina christiana (CCL 32), s. 116.

${ }^{40}$ Por. M. de D re uille, dz. cyt., s. 25 n.

${ }^{41} \mathrm{~J}$. L e c l e r c q, Il richiamo dell'eremo, Praglia 2005, s. 95 n.

${ }^{42}$ Tamze, s. $99 \mathrm{n}$.
} 
Ważnym momentem jest tutaj również homilia. Pomocna rola wspólnoty ma wiele wymiarów i może odnosić się do spotkań formacyjnych, konferencji oraz osobistego dzielenia się własnym doświadczeniem w tym zakresie ${ }^{43}$.

Meditatio w monastycznym doświadczeniu nie jest ćwiczeniem opróżnienia umysłu, wprowadzenia go w stan doświadczenia pustki, poprzez praktykę „uważności" i wewnętrznego oczyszczenia. W życiu religijnym medytacja, będąc żywym twórczym poszukiwaniem prawdy, zakłada pewien wewnętrzny dynamizm, siłę decydującą o jej skuteczności i ostatecznym owocu. Siłą tą jest miłość ${ }^{44}$. Stąd w doświadczeniu religijnym wysiłek medytacyjny nie może pozostać chłodnym intelektualnym przyglądaniem się przedmiotowi, który budzi zainteresowanie. Przeciwnie, pierwotne zdziwienie zrodzone ze spotkania $z$ Bogiem rozpala w człowieku wewnętrzny entuzjazm, pragnienie adoracji, zjednoczenia. Dlatego nawet jeśli wierzący rozpoczyna swą medytację od lektury Pisma, to stanowia one tylko pewne oparcie, na którym wzniesie się cała rzeczywistość życia duchowego prowadząca do komunii z Bogiem. Medytacja nigdy nie zadowala się teoretycznym rozważaniem przedmiotu, lecz pragnie poznania przez zjednoczenie, intuicję, współuczestnictwo. Dlatego w doświadczeniu chrześcijańskim stanowi ona jak gdyby przedpole modlitwy kontemplacyjnej, która ze swej natury jest milczącym miłosnym poznaniem Boga w przestrzeni wiary ${ }^{45}$.

Medytacja w znaczeniu chrześcijańskim jest aktywną postawą całej naszej osoby prowadzącą do odkrycia mistycznego znaczenia Pisma mocą daru mądrości. Dzięki niej słowo zamieszkuje w nas i dokonuje weryfikacji naszej egzystencji. Można powiedzieć, iż podczas lectio to my czytamy słowo, natomiast meditatio słowo niejako „odczytuje" nas, ukazując nam prawdę (często bolesna) o nas samych $^{46}$.

Tak rozumiana medytacja prowadzi nas do kolejnego etapu lectio divina, a mianowicie do oratio. Modlitwa wypływa tutaj $\mathrm{z}$ odnowionej oczyszczonej spotkaniem ze słowem w prawdzie relacji z Jezusem Chrystusem. Nowa postać modlitwy rodząca się w doświadczeniu lectio divina odnosi się do procesu jej „uduchowienia" czy też ,interioryzacji”. Staje się ona po prostu coraz mniej modlitwą naszych warg na rzecz modlitwy serca. Życie modlitwy nie ma nigdy charakteru statycznego, lecz dynamiczny; oratio jest droga przebytą od poziomu ludzkich warg, poprzez proces oczyszczenia serca i nawrócenia aż po spokojne wpatrywanie się w misterium Bożej chwały w procesie contemplatio ${ }^{47}$.

Kontemplacja będąc darem Ducha Świętego pozostaje spotkaniem dwóch wolności i dwóch tajemnic - Boga i człowieka. Nie należy zapominać, iż dar łaski jest otwarciem możliwości wzajemnego powierzenia się i oddania. Modlitwa kontemplacyjna to doświadczenie wiary wewnętrznego jednoczącego spotkania z Bogiem, któremu towarzyszy uświadomienie sobie własnej życiowej sytuacji. Dzięki intuicji wiary coraz lepiej uprzytamniamy sobie fakt, iż nie można zrozu-

\footnotetext{
${ }^{43}$ Por. tamże, s. 83 n.

${ }^{44}$ Por. K. W e n c e l, Oswajanie..., dz. cyt., s. 51 n.

${ }^{45}$ Por. tamze, s. $64 \mathrm{n}$.

${ }^{46}$ Por. J. L e c l e r c q, Il richiamo..., dz. cyt., s. 105 n.

${ }^{47}$ Por. K. W e n c e l, Życie pustelnicze, Kraków 2000, s. 186 n.
} 
mieć siebie samych poza Chrystusem i Jego objawieniem, że ostatecznie sami z siebie niewiele znaczymy. Dzięki contemplatio rozumiemy, iż nasze życie to owoc odwiecznego pełnego miłości udzielania się Boga Ojca w swym Synu. Stąd kontemplacja, w takim kontekście pozostaje prostym odczytaniem sensu i celu życia w wypowiedzianym na gruncie historii Bożym Słowie, Chrystusie. Dlatego można powiedzieć, iż rozpoczyna się ona $z$ chwilą pełnego prostoty i miłości wsłuchiwania w rzeczywistość wypowiadanego słowa Bożego, kierowanego ciągle na nowo w nurcie dziejów do czlowieka ${ }^{48}$. Nie do pomyślenia jest autentyczne życie chrześcijańskie, bez pewnej dozy kontemplacyjnego doświadczenia wiary. To w pogłębionej przestrzeni modlitwy osoba wierząca odkrywa stopniowo nie tylko własną religijną tożsamość, lecz również kształtuje w sobie pełne miłości spojrzenie na Boga obecnego w jej własnym życiu i w dziejach świata. W perspektywie kontemplacji dokonuje się nadto autentyczna inicjacja, wprowadzenie na drogę pogłębionego życia duchowego; jest to droga, na której przyjmuje się za swoje radykalne wymagania Kazania na Górze wraz ze wszystkimi związanymi z tym faktem konsekwencjami ${ }^{49}$. We właściwie pojętym doświadczeniu modlitwy człowiek utożsamia się, w wymiarze wiary i miłości, z postawą Chrystusa względem Ojca i Ducha Świętego, względem wszystkich ludzi, a wreszcie calego świata. Nie powinno zatem dziwić, że ostatecznie modlitewny, zażyły dialog nie tylko przyśpiesza dojrzewanie wiary chrześcijańskiej, lecz nadto decyduje o możliwości autentycznego spotkania z Bogiem. Osoba, której brak codziennej praktyki kontemplacyjnej pozbawia się nie tylko istotnych impulsów ożywiających i intensyfikujących jej religijne doświadczenie. W istocie modlitwa pozostaje podstawowym czynnikiem decydującym o kształcie chrześcijańskiej postawy duchowej, dlatego jej rola zdaje się być niemal niezastapiona. Jakiekolwiek niedomówienia $\mathrm{w}$ tak istotnej dziedzinie niosą szkodę wszystkim tym, którzy jako chrześcijanie mogliby ją z powodzeniem wcielać w życie ${ }^{50}$.

\section{Monastyczne milczenie w kontekście liturgii}

Tajemnica liturgii, przynależąc do porządku tego świata, odsłania głębię zbawczej miłości Ojca, która ukazuje się w Zmartwychwstałym. Możliwość zbliżenia do istoty tego misterium, odnajdujemy jedynie w zmyśle naszej wiary, która przyjmuje Boże słowo, w milczącej kontemplacji działania Boga w świecie i w naszych sercach ${ }^{51}$. Kontemplacja wielkich dzieł Bożych dokonanych w historii zbawienia, które uobecnia i wyraża liturgia dokonuje się w perspektywie naszej wiary. Pustelnicze milczenie wiary w odniesieniu do liturgii Kościoła jest $\mathrm{z}$ jednej strony uważną i czujną wrażliwością wobec przychodzącego słowa - łaski, z drugiej zaś pełnym dynamizmu opowiedzeniem się po Jego stronie. Milczenie rozu-

\footnotetext{
${ }^{48}$ Por. tenże, Oswajanie..., dz. cyt., s. 69 n.

${ }^{49}$ Por. tamże, s. $146 \mathrm{n}$.

${ }^{50}$ Por. A. Ravi e r, Vita umana..., art. cyt., s. $86 \mathrm{n}$.

${ }^{51}$ Por. M. De Dreuille, The Rule..., dz. cyt., s. 189 n.
} 
miane jako postawa dojrzałej wiary w odniesieniu do celebracji liturgicznej można odnieść do dwóch podstawowych momentów: postawy słuchania oraz osobowej relacji i komunii, a więc do wspólnoty. Każdy z tych aspektów nawzajem się przenika, gdyż ostatecznie określa jedną rzeczywistość, niemniej każdy z nich zarazem zaznacza pewną swoistą charakterystykę przynależną jemu samemu ${ }^{52}$.

Do istoty monastycznej liturgii odnosi się ciągle ponawiana czynność aktualizacji Bożego słowa w konkretnym zgromadzeniu eklezjalnym; jest ono żywą wspólnotą wierzących w Chrystusa, zgromadzonych w Jego imię. Było tak od zarania chrześcijaństwa - wyznawcy Chrystusa trwali na modlitwie, karmiąc się słowem Bożym (Dz 4, 42). Od samego początku liturgia słowa stanowiła integralną część Eucharystii, a jej punktem kulminacyjnym była proklamacja Ewangelii. Zastanówmy się, jakie miejsce w tym kontekście zajmuje milcząca postać naszej wiary w relacji do Bożego słowa?

Horyzont milczenia jest podłożem narodzin słowa ${ }^{53}$. We wzajemnym napięciu ich dwojga ukazuje się nie tylko pierwotna potencjalność milczenia, zdolna „wydać" ze swego łona słowo, lecz nadto pojawia się tutaj szczególnie wyraźnie cecha jego relacyjności, sposób bycia „wobec" i „do" tego, co „naprzeciw” - słowa. Pomiędzy milczeniem a słowem nie ma związku konieczności, lecz rysuje się perspektywa wolności jako warunek każdej relacji. Milczenie może istnieć poza wszelkim ludzkim słowem, choć, wydaje się, że słowo nie może istnieć bez pierwotnej przestrzeni milczenia. Toteż każde nasze słowo naznaczone jest charakterystycznym rysem milczenia jako źródła swego pochodzenia. I na odwrót, w źródłowej postaci milczenia zawiera się ślad każdego ze słów ${ }^{54}$.

Tajemnica naszej tożsamości objawiona w doświadczeniu postusznej wiary konkretyzuje się w nadanym nam ,imieniu”, którym Bóg zwraca się do nas w swym słowie. W swej personalnej relacji do Stwórcy przestajemy być kimś anonimowym, jednostka zagubioną w tłumie, a zaczynamy istnieć w pełni jako osoba tworząc wpólnotę-komunię. Jedynie w ,imieniu" postyszanym ze strony zagadującego nas Boga stajemy się kimś bardzo konkretnym, jedynym, osobą różną od każdej innej osoby. Nie jesteśmy już dłużej określoną indywidualnościa, lecz kimś pokochanym w sposób niepowtarzalny, a zarazem rzeczywisty i jedynie twórczy.

Liturgia skupia w sobie, wyraża i zwieńcza zbawcze posłannictwo Kościoła, jak i sens życia pustelniczego ${ }^{55}$. Jej misteryjna rzeczywistość daje sposobność bezpośredniego zbliżenia się, w doświadczeniu wiary, do tajemnicy Jezusa Chrystusa począwszy od wcielenia, przez zmartwychwstanie, aż po powtórne Jego przyjście. Zarówno Kościól, jak i poszczególni mnisi pozostaja egzystencjalnie (a więc łaskawie) włączeni w przestrzeń Eucharystii - dziękczynienie Syna ${ }^{56}$. Moźliwość spotkania i zjednoczenia się z dziękczynną postawą Jezusa Chrystusa wobec Ojca odnosi się wprost do otwartości serca eremity wobec woli Boga Ojca aż

\footnotetext{
${ }^{52}$ Por. K. W e n c e 1, Milczenie podczas liturgii, „Pastores” 4(2005) s. 49.

${ }^{53}$ Por. M. B a ld i n i, Educare all'ascolto, Milano 1993, s. 13.

${ }^{54}$ Por. K. W e n c e 1, Milczenie, dz. cyt., s. 47 n.

${ }^{55}$ Por. Konstytucje, s. 69

${ }^{56}$ Por. tamze.
} 
po rzeczywistość ostatecznego oddania w przestrzeni doświadczenia paschalnego. Krzyż i Eucharystia pozostają w najgłębszej wzajemnej relacji. Przestrzeń krzyża kreśli najbardziej czytelny znak wydania się mnicha Bogu $\mathrm{w}$ posłuszeństwie i wdzięczności dla dobra drugiego człowieka. Włączone w dynamikę Eucharystii mnisze życie, jak i śmierć jest tutaj łaskawie przemienione mocą obecności Tego, który umarł jako jeden $\mathrm{z}$ nas. Perspektywa otwarcia przed człowiekiem nowej jakości życia ma swój początek w darze uczestnictwa w Eucharystii Syna. Odmieniona całkowicie nowa postać ludzkiego źycia jest nam podarowana w Chrystusowym wydaniu się Ojcu, które wyraża Eucharystia ${ }^{57}$.

Określenie Eucharystii przez pierwotną wspólnotę uczniów mianem „Wieczerzy Pańskiej” czy ,stołu Pańskiego” wskazuje na wiarę, iż to sam Pan zwołuje pustelniczą wspólnotę i jednoczy ją w swej obecności. Chrystus zmartwychwstały pozostaje obecny wśród wierzących wierzących, którzy gromadzą się na świętowaniu Eucharystii, która pozostaje celebracją Jego obecności. Jednym z zasadniczych momentów liturgii eucharystycznej jest wskazanie, iż sam Chrystus jako Pan wspólnoty uczniów zaprasza na wieczerzę. On sam jest Gospodarzem uczty a zarazem jest nią sama; to ona uobecnia Go i wyraża. Ponieważ obecność Chrystusa zmartwychwstałego ma tutaj charakter rzeczywisty i osobowy, a więc jest jawna, to jednak odsłania się ona w znaku chleba i wina, co decyduje o jej skrytości. ${ }^{58}$ Ta sakramentalna obecność w jej osobowej dynamice jest naznaczona zasadniczym rysem relacyjnym, który swą skuteczność odnajduje w relacji wiary z każdym z nas, jak i z całą wspólnotą Kościoła. Milcząca osobowa obecność Chrystusa w Eucharystii jest darem przywołania każdego z nas do bliskiej intymnej relacji, w którym ofiarowuje nam samego siebie w żywotnym odniesieniu wiary ${ }^{59}$.

Tajemnicę konkretnej obecności Boga w Eucharystii mnich przyjmuje jedynie w prostym akcie wiary jako milczeniu wrażliwego serca. Postrzeganie i percepcja Bożej chwały nie jest prostym, chłodnym estetycznym oglądem obecności Boga, lecz wiąże się z porywem ludzkiego serca pociagniętego, pochwyconego przez to, co ujrzało i przyjęło w siebie. Milcząca percepcja zmysłu wiary to nie jedynie postawa pasywności, lecz pełen dynamiki zwrot w kierunku źródła paschalnego światła, które oświeca, przemienia, daje życie. Zderzenie z rzeczywistością Bożej Obecności-Milczenia w przestrzeni modlitwy liturgicznej prowadzi nas do zbudzenia tych pokładów wolności, dzięki którym stajemy się dziećmi w wymiarze ducha ${ }^{60}$.

Nasze milczące opowiedzenie się po stronie Boga jest darem Jego obecności, która przywołuje, wychodzi nam na spotkanie. Odpowiedź naszej wolności w poddaniu się przemożnemu wpływowi Jego mocy jest echem pierwotnie rozlegającego się wołania-słowa w głębi milczenia naszej wiary. W liturgii ciaggle od nowa otwieramy się na - obecny dla nas w Chrystusie - Boży świat. Jest to świat niezmierzonej kreatywności i mocy, dostępny dla wolności człowieka wyłącznie

\footnotetext{
${ }^{57}$ Por, tamże, s. 70.

${ }^{58}$ Por. A. G i a b b a n i, L'eremo, Morceliana 1945, s. 140.

${ }^{59}$ Por. tamże, s. 145.

${ }^{60}$ Por. K. W e n c e l, Milczenie, dz. cyt., s. 162.
} 
dzięki paschalnemu darowi miłości Ojca. W przestrzeni liturgicznej odkrywamy światłość Bożej obecności, które jest źródłem milczenia i pokoju naszych serc ${ }^{6 !}$.

Dar przyjęcia Bożej obecności w Eucharystii jako ostatecznej podstawy a zarazem kresu kamedulskiej drogi wiedzie na spotkanie z rzeczywistością coraz to pełniejszą i głębszą. W perspektywie milczenia naszego serca Bóg ukazuje się jako dar, jako wspólnota Osób. Decyzja Bożego wkroczenia w naszą historię, zaangażowania się na rzecz przemiany a ostatecznie zbawienia świata, które celebrujemy w liturgii, określa zasadniczo samo centrum monastycznej duchowości. Kształtuje się ona w atmosferze szeroko rozumianego milczenia. Promieniowanie objawiającej się, milczącej Obecności-Trójcy, jako źródła wszelkiego dobra, prawdy i piękna otwiera przed nami horyzont tej pełni istnienia, którą nazywa się darem odwiecznej Miłości ${ }^{62}$.

Nasze życie zjednoczone z Chrystusem eucharystycznym zostaje milcząco przemienione mocą śmierci Tego, który umarł jako jeden z ludzi. W męce i śmierci Chrystusa, który przyjął ludzką naturę zawiera się zarówno śmierć jak i narodziny do nowego życia każdego z nas. Możliwość otwarcia przed człowiekiem perspektywy nowej jakości egzystencji - poprzez uczestnictwo w Eucharystii Syna - jest podarowana w przestrzeni zastępczego charakteru Jego ofiary. Chrystus przyjmując na siebie aktualną sytuacje człowieka daje nam uczestnictwo (poprzez wspólnotę eklezjalną) w swej Eucharystii. Stąd też nowa jakość egzystencji ofiarowana w Chrystusowym wydaniu się Ojcu wyraża się w możliwości milczącego, laskawego, wolnego uczestnictwa mnicha w bycie Syna ${ }^{63}$.

Ostatecznie, milczące a zarazem pełne dramatycznych napięć współdziałanie pomiędzy Bogiem a mnichem aktualizuje się jedynie „w Chrystusie” (en Christoi) poprzez dar łaski w wymiarze sakramentalnym. W eucharystycznej postawie dziękczynienia Syna odnajdujemy miejsce dla swego własnego, indywidualnego oddania się Ojcu, i w tym oddaniu realizuje on swą osobowość w sensie teologicznym. Sakramentalna postać laski pośredniczy w odniesieniu człowieka do wymiaru absolutnej wolności Boga, włączając go poprzez Eucharystię Chrystusa (w Duchu Świętym) w odwieczną miłość Ojca ${ }^{64}$.

Przy czym communio sanctorum nie może być ujmowane w wymiarze naturalnym jako ,solidarne współbycie”, lecz jako milczącą wewnętrzną solidarność miłości (caritas), która wypływa z Chrystusowego krzyża i Eucharystii. Wspólnota świętych jest więc komunią osób zjednoczonych z Chrystusem w wymiarze łaski-miłości, udzielanej jej nieustannie w rzeczywistości sakramentalnej. Jest to zatem wspólnota, której podstawą staje się nieustanny dialogiczny proces wymiany miłości pomiędzy poszczególnymi osobami, mający swe oparcie w Chrystusowym „byciu-dla-drugiego"65.

Milcząca postać uczestnictwa mnicha we wspólnocie świętych zostaje zaznaczona tym pełniej, im bardziej staje się on osobą tzn. im mocniejsze jest jego

\footnotetext{
${ }^{61}$ Por. M. De Dre u ille, The Rule..., dz. cyt., s. $167 \mathrm{n}$.

${ }^{62}$ Por. K. W e n c e l, Hans Urs von Balthasar. Teologia chwały, Kraków 2001, s. 103 n.

${ }^{63}$ Por. A. R a vi e r, Vita umana..., art. cyt., s. 59 n.

${ }^{64}$ Por, tamże.

${ }^{65}$ Por. J. L e c l e r c q, Il richiamo..., dz. cyt., s. 137 n.
} 
usytuowanie w rzeczywistości łaski-miłości. Ugruntowanie w miłości i wynikające zeń działanie, stanowi dar uczestnictwa konkretnego człowieka w powszechnym posłannictwie Chrystusa. Relacyjny, osobowy charakter odniesień w communio sanctorum realizowany w dialogicznej postaci miłości i wzajemnym milczeniu-słuchaniu umożliwia - na zasadzie analogicznej do Chrystusowego wydania się za człowieka - wzajemną wymianę darów duchowych: modlitwy, ofiary za drugich. Moźliwości przepływu tychże dóbr są z zasady nieograniczone wymiarem czasowo-przestrzennym, obejmując sobą także Kościół zbawionych ${ }^{66}$.

\section{Trzy momenty pustelniczej dyscypliny}

Pełen mądrości, dyskrecji i umiaru styl życia eremickiego, jaki proponuje ojciec Pawel, oparty zostaje na kilku zasadniczych elementach określających jego specyfikę. W rzeczywistości można mówić o trzech ascetycznych zasadach pustelniczej dyscypliny: praktyce milczenia, samotności oraz postu, które odróżniają tę drogę od pozostałych form realizacji chrześcijańskiego powołania. Łaska milczenia niesie z sobą duchową energię, dającą możność przemiany serca i otwarcia ludzkiego ducha na światło kontemplacji. Jego praktyka rozpoczyna się od ascezy języka, którego mądra kontrola umoźliwia panowanie nad wszystkimi wymiarami ludzkiej osobowości. Dla Justynianiego milczenie odnosi się ostatecznie do takiej duchowej dynamiki człowieka, które owocuje wewnętrznym uwrażliwieniem i przejrzystością wobec kaźdego aspektu Bożej prawdy ukazującej się w świecie. Milczenie zakreśla przedpole kontemplacji, horyzont miłosnego odniesienia i dialogu, w którym przeplatają się wzajemnie słowo i głęboka cisza ${ }^{67}$.

Drugim charakterystycznym momentem pustelniczej ascezy jest praktyka życia w samotności ${ }^{68}$. W przekonaniu ojca Pawła nie ma ona jednak nic wspólnego z postawą wyobcowania, ucieczki czy mizantropii. Przestrzeń samotności w eremickim doświadczeniu wiary posiada dwubiegunową strukturę: z jednej strony pomaga uwolnić się od pychy i próżności, a więc dominacji ,ja” w naszej codzienności. Uzyskany horyzont wolności umożliwia, z drugiej strony, otwarcie „oka” ducha na światło Bożej chwały, dając sposobność przejścia od życia „dla siebie” w stronę istnienia „dla Boga”, uporządkowania całości ludzkiej egzystencji w kontekście logiki Bożego królowania. Dlatego też dla ojca Pawła: „Nic nie jest tak stosowne i konieczne dla tych, którzy prowadzą życie samotne, jak przebywanie w celi, siedząc w milczeniu"69"

Post, modlitwa i jałmużna wyznaczają ostatni biegun pustelniczej ascezy, a zarazem podstawowy wyznacznik duchowego wzrostu i życia wiary. Jezus przedkładając uczniom te (zakorzenione w tradycji judaizmu) wskazania, wyją je z kontekstu stricte prawnego podkreślając, iż ich zasadnicza wartość leży w moż-

\footnotetext{
${ }^{66}$ Por. K. W e n c e 1, Życie pustelnicze, dz. cyt., s. 159 n.

${ }^{67}$ Por. A. G i a b b a n i, L'eremo..., dz. cyt., s. 127.

${ }^{68}$ Por. Konstytucje, dz. cyt., s. 6; K. W e n c e 1, Zycie pustelnicze, dz. cyt., s. $31 \mathrm{n}$.

${ }^{69}$ Konstytucje, dz. cyt., s. 74.
} 
liwości pielęgnowania miłości w odniesieniu do Boga i drugiego człowieka. Ich praktyka decyduje o przyjęciu służebnej postawy wobec Bożego słowa, wymagającej „czystości serca” i uczynków miłosierdzia.

Całość duchowego dziedzictwa Justynianiego przybiera ściśle chrystologiczna, teologalną orientację. Zarówno przykładem życia, jak i nauczaniem zdaje się nieustannie podkreślać, iż struktura chrześcijańskiej wiary jest kształtowana wokól jednego jądra, którym jest wydarzenie miłości, którą Ojciec powierzył światu w swym Synu. Pelnia prawdy ukazanej w Chrystusie pozostaje darem tej miłości, której mądrość i pierwotne piękno objawiają się z niezachwianą konsekwencją w perspektywie ludzkich dziejów ${ }^{70}$.

Chrystus przyjmuje los człowieka, by przepełnić go ukrytym dotąd światłem i mocą które mają swe źródło w zwycięstwie Paschalnego Poranka. Ostatecznie okazuje się, iż prześwietlona blaskiem Zmartwychwstałego pustelnicza codzienność zostaje osadzona w nowej perspektywie - jej znaczenie i sens zaczynają krążyć wokół nowych wartości i celów. Dzieje się tak dlatego, iż spotkanie Boga w doświadczeniu kontemplacyjnym sięga najbardziej źródłowych momentów egzystencji człowieka - wzrok Chrystusa dotyka zawsze najintymniejszych strun ludzkiego istnienia, pozostawiając w nim trwały ślad paschalnej nadziei.

Powołanie eremity to rodzaj „milczącej obecności” wzniecającej nieco duchowych iskier radości i pokoju, braterstwa i zrozumienia, przyjaźni i bezpieczeństwa. Reszta pozostaje zdumiewającym misterium okrytym płaszczem milczenia.

\section{PODSUMOWANIE}

Wiara chrześcijańska odnosi się do wydarzenia miłości, jaką Bóg powierzył człowiekowi przez Syna w Duchu Świętym. Pełnia prawdy ukazana w Chrystusie pozostaje darem tej miłości, której mądrość i pierwotne piękno objawiają się z niezachwianą konsekwencją w perspektywie ludzkich dziejów. Chrystus przyjmuje los człowieczy, by przepełnić go nieznanym dotąd światłem i moca, które posiadają swe źródło w zwycięstwie ukazanym w świetle Paschalnego Poranka.

W każdej kulturze można odnaleźć ludzi, którzy oddalając się od biegu zwykłych codziennych spraw, wchodząc w nurt samotnej egzystencji, postanowili nadać własnemu istnieniu moźliwie pełny wyraz i znaczenie. Droga chrześcijańskiej samotności nie jest przesłonięta gorzkim mrokiem osamotnienia, gdyż jej istota odnosi się zawsze do osobowej obecności, dialogu i spotkania człowieka z Bogiem i braćmi. Powolanie kamedulskie sprowadza się w swej istocie do posłuszeństwa głosowi Ojca, który wyprowadza człowieka na pustynię, by Jezus stał się jedynym przedmiotem jego myśli, pragnień, miłości. Eremickie doświadczenie samotności, postu i milczenia przenika w głąb paschalnego misterium Chrystusa, w którym wymiar hańby, ubóstwa i ogołocenia owocuje, paradoksalnie, pełnią życia. Pustelnik z cała świadomością żyje niejako „na marginesie” społeczeństwa, $\mathrm{z}$ własnego wyboru staje się nie-użyteczny, by tym mocniej podkreślić prawdę

\footnotetext{
${ }^{70}$ Por. J. L e c 1 e r q, Il richiamo..., dz. cyt., s. 123 n.
} 
ukazaną w świetle logiki Bożego królestwa, a jednocześnie obnażyć jałowość życia zamkniętego w ramach „czasu marnego". Pisał T. Merton:

Wydaje mi się także, że życie samotne realizuje powyższe teksty, według ufnych słów Psalmisty $(39,18)$ : „Ja zaś jestem ubogi i nędzny, ale Pan troszczy się o mnie". Żyjemy w ustawicznej zależności od tej miłosnej dobroci Ojca i dlatego całe nasze życie jest pełne wdzięczności - jest ustawiczną odpowiedzią na Jego pomoc, która przychodzi do nas w każdej chwili. Myślę, że każdy - jeśli jego powołanie jest prawdziwe - doświadcza tego ${ }^{71}$.

Niewątpliwie, życie pustelnicze posiada znamiona walki i zmagania, jakie człowiek podejmuje, by rozpoznać prawdę swego istnienia w Chrystusowych promieniach łaski. W takiej optyce powołanie eremickie przyjmuje wymiar prorocki, tzn., iż czytelność jego świadectwa wskazuje właściwy kierunek poszukiwań wszystkim tym, którzy pragną odnaleźć rozsiane w świecie ziarna prawdy.

${ }^{71}$ T. M e r t o n, Myśli w samotnosici. Chleb żywy, Kraków 1975, s. 97. 